\section{TEM Flat Embedding Technique}

Louisa Howard, Dartmouth College,

Duane Compton \& Alejandro Saredi, Dartmouth Medical School

Individual BHK-21 (Baby Hamster Kidney-21) cells growing on $25 \mathrm{~mm}$ photo-etched alpha-numeric glass coverslips (Belico $\mathrm{Co}_{\text {.) }}$ ) are identified by phase contrast ricroscopy and photographed. (Saredi, Howard and Compton, 1996). This method should work for other cell lines, but likely will require some empirical adjustment of the times, concentrations, and $\mathrm{pH}$.

1) The coverslips are fixed in $2 \%$ glutaraldehyde in $0.1 \mathrm{M} \mathrm{Na}$ Cacodylate buffer $\mathrm{pH} 7.4$ for one hour at room temperature.

2) Rinse three times in $0.1 \mathrm{M} \mathrm{Na}$ Cacodylate buffer $\mathrm{pH} 7.4$.

3) Post-fix in $1 \% 0 \mathrm{SO} 04$ in $0.1 \mathrm{M} \mathrm{Na}$ Cacodylate at $\mathrm{pH} 7.4$ for 1 hour at room temperature.

4) Rinse in $0.1 \mathrm{M} \mathrm{Na}$ Cacodylate at $\mathrm{pH} 7.4$.

5) Rinse in distilled $\mathrm{H}_{2} \mathrm{O}$.

6) En-Bloc stain in $2 \%$ Uranyl acetate in distilled $\mathrm{H}_{2} \mathrm{O}$ for 30 minutes in the dark at room temperature.

7) Rinse in distilled $\mathrm{H}_{2} \mathrm{O}$.

6) Dehydrate through EtOH series: $30 \%, 50 \%, 70 \%, 85 \%, 95 \% ; 3-5$ minutes each.

9) Three 5 minute changes in $100 \%$ EtOH

10) Four 5 minute changes in Propylene oxide in $60 \mathrm{~mm}$ glass petri-dishes. Make sure coverslips stay covered with fluids at all times.

11) Four changes of Epon/Araldite:Propylene oxide 1:1 mixture. Make sure coverslips stay covered with fluids at all times.

12) The flat-embedded samples are left overnight in a dessicator (NO vacuum) to remove Propylene oxide.

13) Fresh resin from the same batch is removed from freezer and thawed for about 1 hour. Coverslips are carefully removed from glass petri-dishes. Excess Epon/Araidite is removed from bottom surfaces by wiping with cotton swabs. Be sure to keep track of which side is the CELL SIDE! Coverslips are placed in clean, flat-embedding slide mold and a thin layer of fresh epon/araidite is added, by drops, to the surface of the coverslip. Leave for one hour.

14) Coverslips are placed in a $60^{\circ} \mathrm{C}$ oven and Epon/Araldite is fully polymerized for 24 hours.

15) Remove coverslip from heat. Check bottom suface of coverslip. GENTLY remove any epoxy layer from the bottom surface with fine sandpaper (120-240 grit). This will expose the glass surface. Glass is removed by etching in cold concentrated hydrofluoric acid (store HF at $4^{\circ} \mathrm{C}$ for 24 hour before use) (Moore, 1975; Rieder and Bowser; 1987). Once the glass is etched away, the plastic water is rinsed thoroughly with distilled water and then dried. Etching times: Belico etched glass coverslips - 2.5 to 6 minutes, depending on temperature of $\mathrm{HF}\left(4^{\circ} \mathrm{C}-15^{\circ} \mathrm{C}\right)$. Be careful not to scratch surface during water rinse. Works $100 \%$, with a nice, clean surface

16) Mark area of interest $t_{1}$ using a dissecting scope. Place epoxy square inside slotted, plastic petri-dish. Insert a single edge razor through, the slot:: tap GENTLY with hammer, in order to cut out section of interest. The slotted petri-dish will keep cut pieces from flying across the lab bench. Attach these pieces to blank epoxy blocks with crazy glue. Mark each block with the two letter code for refer-

ence. After glue has set, check block for strong attachment, then CAREFULL $Y$ trim away excess epoxy around chosen cell or cells. In this case, each etched square is about I

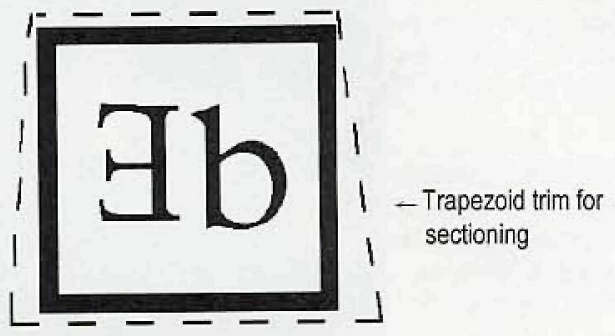

Cell side up, after embedding $\mathrm{mm}^{2}$.

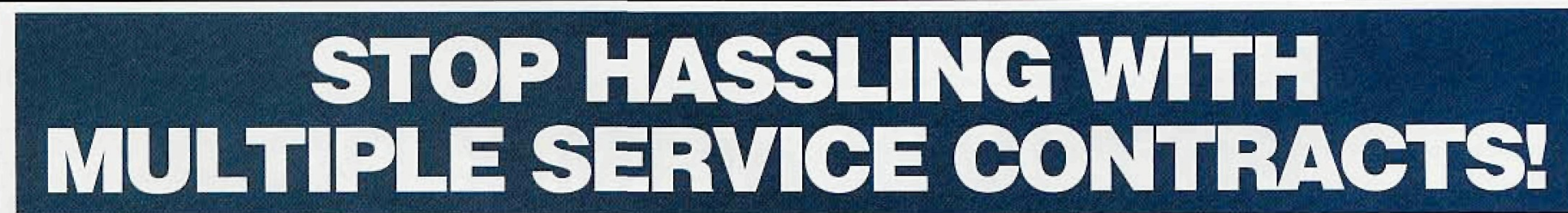

START by putting all of your instruments under one contract with MAS

(regardless of make or model). Our expert EM SERVICE GROUP has the knowledge and skill to keep your instrumentation working at its best.

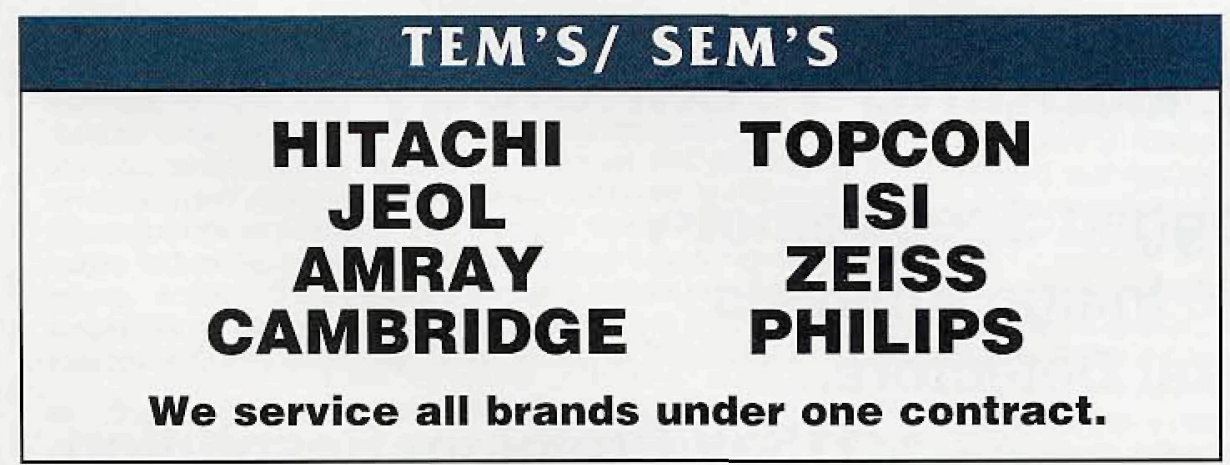

PREP EQUIPMENT

ULTRAMICROTOMES DUPONT \& RMC VACUUM COATERS SPUTTER COATERS MECHANICAL PUMPS TURBO PUMPS PLASMA ASHERS

WE SERVICE COMPUTER CONTROLLERS BEAM BLANKERS WATER CHILLERS
Contracts and On-Demand

Emergency Service at

Reasonable Rates from

Factory Trained Specialists.

1-800-421-8451

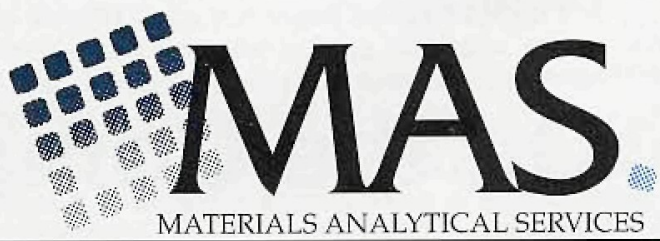

3597 Parkway Lane • Suite 250 • Norcross, Georgía $30092 \cdot 770-448-3200$ - FAX 770-368-8256 or 616 Hutton Street • Suite 101 - Raleigh, North Carolina 27606 • 919-829-7041 * FAX919-829-5518 ADVANCED ANALYTICAL PRODUCTS AND SERVICES 
References:

Moore, M.J., 1975, Removal of glass coverslips from cultures flat embedded in epoxy resins using HF. Microscopy 104, 205.

Rieder, Conly and Bowser, Samuel, 1987, "Correlative LM and EM on the same epoxy section", in Correlative Microscopy in Biology, Chapter 11 (ed. M.A Hayet), pp. 249-277, Academic Press

Saredi, A., Howard, L. and Compton, D., 1996 "NuMa assembles into an extensive fliamentous structure when expressed in the cell cytoplasm". J. Cell Sci. 109: 619-630.

Coverslip Source:

Belico Glass co.

P0 Box B

340 Edruduo Road.

Vineland, N.J. 08360

$1-800-257-7043$

Each etched square is about $1 \mathrm{~mm}$ with 2 letters or 1 letter/1 number marking center area of each square. For example:

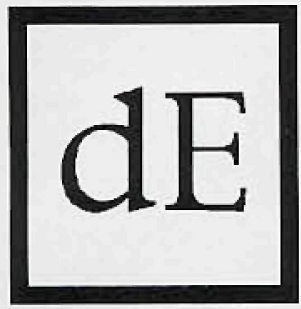

Cell side up, before embedding

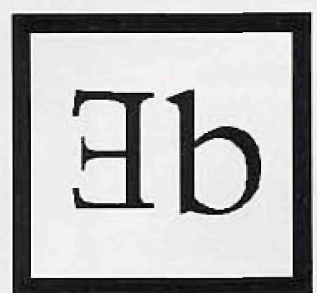

Cell side up, after embedding

\author{
EPON I ARALDITE: \\ $10 \mathrm{~mL} \quad$ LX112 (POLYBED812, etc.) \\ $10 \mathrm{~mL} \quad$ Araldite 502 \\ $24 \mathrm{~mL}$ DDSA \\ $0.9 \mathrm{~mL}$ DMP 30 (added just before use)
}

Mix together first three by shaking vigorously. Warm in $50^{\circ} \mathrm{C}$ oven for $5-10$ minutes to improve mixing. Add DMP-30 and mix vigorously. Resin mix may turn orange depending on $\mathrm{pH}$ of DMP-30. Remove air bubbles with vacuum for about 30 minutes. Store aliquots of resin mix in 5 or $10 \mathrm{~mL}$ disposable syringes in $-20^{\circ}$ C freezer; will keep for 1 week. Be sure to use same resin mix for all steps of infiltration.

* The hydrofouric acid is used straight from the bottle. It comes as $48 \%$, with a well designed pour spout to avoid spilling, splashes and drips down the side of bottle. Use under fume hood! It is a strong, dangerous acid, as are all concentrated acids. Bottle comes with all the caveats and recommended precautions. Since only about $5 \mathrm{~mL}$ is used in a closed plastic petri dish, lab coat, neoprene gloves and eye protection are sufficient precautions.

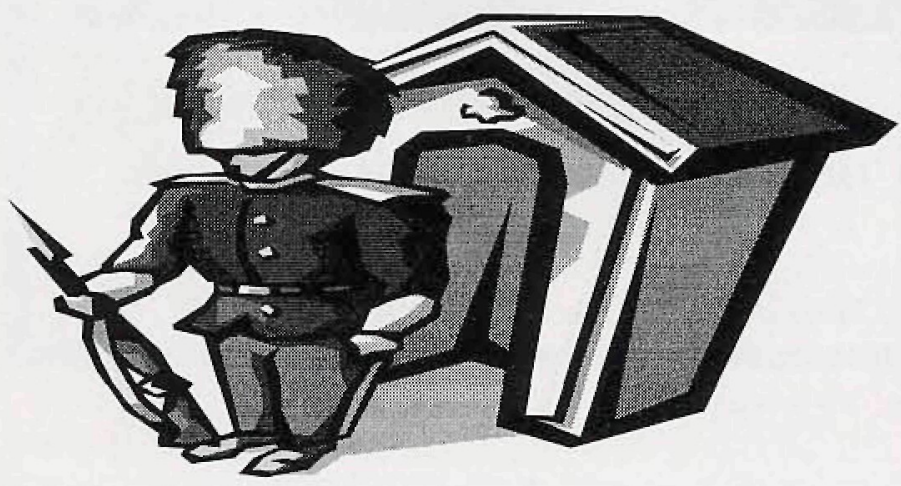

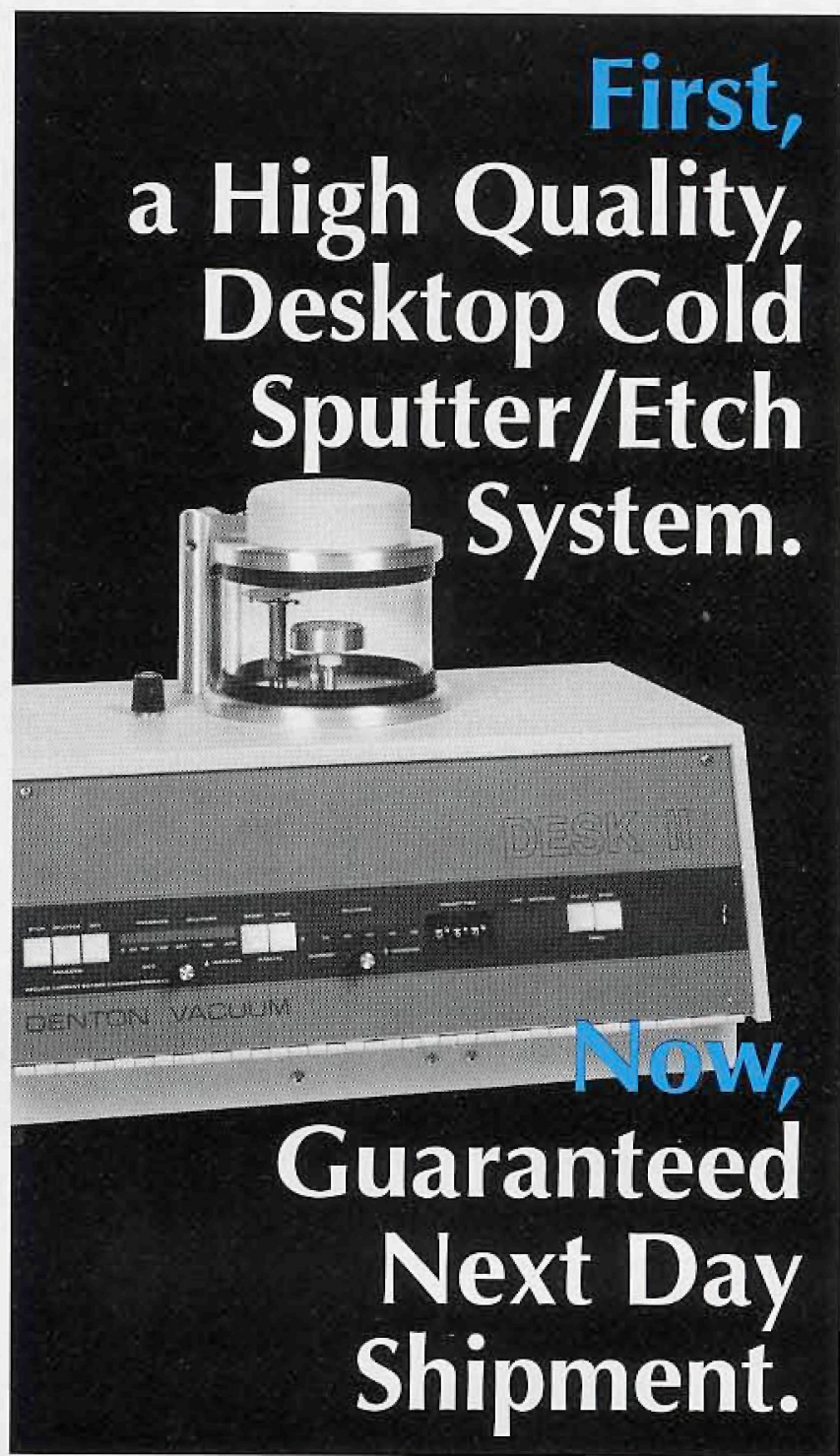

Order Denton's standard Desk II System by noon today and get guaranteed shipment tomorrow or Denton pays the freight.

The Desk II produces uniform, conductive, fine grain $\mathrm{Au} / \mathrm{AuPd}$ coatings in under three minutes and is the highest quality desktop system available.

\section{The Desk // features:}

- Automatic or manual operation

Easy to read digital vacuum and current gauges

- Optional carbon evaporation accessory

For more information, look no further than Denton... where both Quality and Delivery invite comparison.

\section{DENTON VACUUM INC.} 1259 North Church St. Moorestown, NJ 08057 USA
Tel: (609) 439-9100

FAX: (609) 439-9111

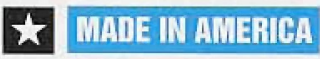

Next day shipment must be requested at time of order. 